\title{
The Foundational Myth of Mercosur and the European Union Analogy
}

\author{
Paulo Emílio Vauthier Borges de Macedo*
}

(Received 03 August 2018; accepted 23 October 2018)

\begin{abstract}
This Article criticizes two trends on the Brazilian literature of communitarian law: A mental exercise that can only be termed as an "EU analogy" and a need to evoke the Congress of Panama of 1826 as the origin of Mercosur. As odd as it may seem, those trends are somewhat connected. Comparisons between the European Union and Mercosur abound in scholarly works, and they became so popular that a more simplified version of this comparison came into being. When explaining the current dilemma that Mercosur faces - or any other predicament as well—Brazilian scholars often tend to provide only one solution consisting in a vague reference to the supranational character of the European Union. This reference appears out of context and solves any problem. A trend so common as the EU analogy exemplifies that some Brazilian experts on communitarian law have also assumed an idealized version of our neighbors' take on the Latin America integration. Apparently, Mercosur dates back to the Congress of Panama of 1826 and Simón Bolívar's ideals on Latin American integration. The story faces several historical obstacles and yet has spread so rapidly that it has acquired the stature of a true myth. This work presents these two inclinations and contends that one relies on the other. Rather than providing an accurate explanation, as one would expect on a scientific text, they justify a certain concealed intent. This Article employs an inductive method of approach and relies on primary sources to explain the foundational myth so to prevent historical misconceptions.
\end{abstract}

Keywords Mercosur; European Union; Simón Bolívar

\section{A. Introduction}

History is not a very useful discipline. It does little to solve practical problems. Granted, some deem it a "comprehensive field of knowledge" and pledge that, by studying history, scholars are better equipped to comprehend the root of a sweeping collection of problems that affect today's society. Legal history may well be one-step ahead of history in general given the practical nature of its object. A practitioner of law may deliver a better ruling by understanding the origins of a legal institute or rule. Legal history also enables us to unveil the bias behind seemingly neutral mental resources. The purpose of this Article is to disclose the ideological reasoning behind the comparison often made by Brazilian scholars between the European and the Latin American integrations by delving into the historical reasons that drove Brazil toward said process. Hopefully, history may shed light on the true meaning of that comparison.

\footnotetext{
${ }^{\star}$ Doctor, Professor of International Law at the University of Rio de Janeiro (UERJ), Deputy-Head of the Master and Doctorate Programs of the Law School of UERJ, author of Catholic and Reformed Traditions in International Law (Springer, 2017), e-mail: borgesmacedo@hotmail.com.
}

(C) 2019 The Author. Published by Cambridge University Press on behalf of the German Law Journal. This is an Open Access article, distributed under the terms of the Creative Commons Attribution licence (http://creativecommons.org/licenses/by/4.0/), which permits unrestricted reuse, distribution, and reproduction in any medium, provided the original work is properly cited 
For very different reasons, today both the European Union and Mercosur are in a crisis. Unlike the former, the latter aimed at simply establishing a common market between its member states. Needless to say, the steps that were taken to achieve said purpose and the overall historical development of Mercosur's integration fall well behind those of the EU. Yet, both undertakings relied heavily on democratic acquiescence, and much effort came into steering popular opinion towards embracing and legitimizing integration. One may well place Mercosur as the centerpiece of a sociological myth: Allegedly, Latin American integration has been a political pursuit of Latin American States ever since their independence in the nineteenth century. Mercosur would then represent the culmination of all of the previous efforts to that end, the final act in a series of episodes that date back to the ideals of Simón Bolívar and the Congress of Panama of 1826 .

Like every myth, this one fulfils a role not only of explaining a certain state of affairs, but also of justifying a desirable trend. Since the early $1990 \mathrm{~s}$, fertile, though unrealistic, literature arose in the Brazilian universities arguing for Mercosur to follow the example of the EU and, thus, to transcend its original purpose of establishing a mere common market. The Latin American peoples, the "deep sociological forces" behind the integration process, yearned for more. As reality revealed the rudimentary stage in which the integration process languished, and as the promised customs union never came to be, a sense of utter failure took over scholars and government officials alike. A better understanding of the true forces behind the Latin American integration from the Brazilian perspective, however, may reveal that Mercosur has not failed-at least not to the extent one initially is led to believe. From the start, Brazilian authorities held onto a pragmatic agenda; furthering the integration beyond controlled limits was foreseen, yet ill-favored in the eyes of many.

\section{B. The Foundational Myth}

The story of the origin of Mercosur, as told by Brazilian scholars, is but an idealized version of our neighbors' take on the Latin America integration. As early as the beginning of the $1990 \mathrm{~s}$, when Mercosur was at its initial stage, hardly any textbook on Mercosur or on Latin American integration dared deviate from this foundational myth. ${ }^{1}$

The reason why people resorted to a myth may only be fully comprehended by first grasping the importance of the Congress of Panama of 1826. Shortly after the independence of the former Spanish colonies, the great libertador Simón Bolívar took to advocating the integration of the recently established republics of America. In 1815, in the Charter of Jamaica, Bolívar expressed the desire to form a confederation of the states that once belonged to Spain: "More than anything, I wish to see rise in America the greatest nation of the world, not so much because of its size and richness, but because of its freedom and glory." And:

How wonderful would it be if the Peninsula of Panama becomes to us that which Corinth was for the Greek! I hope one day we may be fortunate to witness a sovereign conference of all the

\footnotetext{
${ }^{1}$ The examples abound. See generally Ricardo Soares Stersi dos Santos, Mercosul E Arbitragem Internacional Comercial: Aspectos gerais e algumas possibilidades 21-74 (Livraria Del Rey ed., 1997); José Gabriel Assis de Almeida, Mercosul: manual de Direito da Integração 4 (2001); André Lipp Pinto Basto Lupi, Soberania, OMC E Mercosul 202-06 (2001); Leonardo Arquimimo de Carvalho, Os processos de integração econômica regional da União Européia e do MERCOSUL: breve abordagem histórico-evolutiva, 5/6 SCIENTIA IURIS 59 (2001/2002); Sidney Guerra, Mercosul: do ideal bolivariano para a realidade atual (e quem sabe futura?), 1 REVISTA DE LA SECRETARÍA DEL TRIBUNAL PeRMANENTE DE REVISIÓN 275 (2013), http://revistastpr.com/index.php/rstpr/article/view/14/17; Elisa de Sousa Ribeiro Pinchemel, Instituições e Integração Regional na América do Sul: Uma análise comparativa entre ALADI, Mercosul e UNASUL 30-32 (Apr. 22, 2016) (doctoral thesis, University of Brasília), http://repositorio.unb.br/bitstream/10482/19998/ 1/2016_ElisaSousaRibeiroPinchemel.pdf. The first author from this list has recently published a work whose main purpose is to display the myth as Mercosur's origin. Ricardo Soares Stersi dos Santos, A integração latino-americana no século XIX: antecedentes históricos do Mercosul, 29 REVISTA SEQÜÊNCIA 177 (2008), https://periodicos.ufsc.br/index.php/sequencia/ article/viewFile/14953/13644.
} 
republics' representatives to address issues such as peace and war with the nations from the other three parts of the world. ${ }^{2}$

At that time, the newly independent countries of the former Hispanic American Empire were politically feeble and constituted an easy prey for any Holy Alliance sponsored intervention. Bolívar correctly thought that a unified America would deter any new imperialistic endeavors. ${ }^{3}$ But there is more to his project than a mere defensive alliance. It is often contended that Rousseau's and Abbé Saint Pierre's Project for Perpetual Peace exerted a considerable influence over Bolivar, ${ }^{4}$ so much so that his ultimate goal would be to actually establish a political authority - a permanent assembly composed of plenipotentiary representatives of its members, superior to all the forming States. This authority would possess the power to raise and maintain armed forces of its own and to arbitrate conflicts between the member countries. It would uphold the ideals of republicanism and abolition of slavery in opposition to the old European non-egalitarian monarchies. According to Bolívar, only an organization of this stature would safeguard the American Republics from internal and external aggressions as "a shield for our new destiny."

Therefore, Bolívar envisaged a supranational authority that would fulfil both political and ethical goals. Scholars have yet to reach a conclusion as to whether Bolívar indeed advocated the notion of a lay state, ${ }^{6}$ but one should not neglect the role of religion for the libertador. In the saying "same people, same language, same customs and same religion,"7 Catholicism is portrayed as fulfilling two major purposes: (1) providing a fertile ground from which said ethics would flourish; and (2) serving as a religious bond bringing together the different peoples.

And Bolívar pursued his dream. Between June and July of 1826, the Congress of Panama took place. Four countries answered the calling: Colombia, Peru, Mexico, and the Centre-American Republic. Brazil, the United States, Great Britain, and the Netherlands were invited as observers, but only the latter two bothered to send their delegations. There, they sought to form a perpetual alliance for the preservation of their independence and the abolition of slavery. They also sought to establish future meetings to openly discuss, among other issues, integration. ${ }^{8}$

The Congress failed in its objectives, but allegedly planted the seeds for Latin American integration. At this point, the line between fable and reality is blurred. Did that movement perceive Brazil as one of their own or as a threat? And more importantly: How did the Brazilian authorities respond to that movement?

\footnotetext{
${ }^{2}$ Comisión Presidencial para la Conmemoración del Bicentenario de la Carta de Jamaica [Presidential Commission for the Commemoration of the Bicentennial of the Charter of Jamaica], Simón Bolivar, Carta de Jamaica, 1815-2015 (2015). On page 21: "Yo deseo mas que otro alguno ver formar en America la mas grande nacion del mundo, menos por su estencion y riquesas, que por su libertad y gloria." And later, on page 29:

¡Que bello seria que el Ystmo de Panamá fuese para nosotros lo que el de Corinto para los Griegos.! ¡ ojala que algun dia tengamos la fortuna de instalar allí un augusto Congreso de los Reprecentantes de las Republicas, Reynos é Ymperios á tratar y discutir sobre los altos intereses de la Paz y de la Guerra, con las naciones de las otras tres partes del Mundo.

${ }^{3}$ Simón Bolífar, Doctrina del Libertador 4-6 (3d ed. 2009).

${ }^{4}$ Elen de Paula Bueno \& Victo Arruda Pereira de Oliveira, O Congresso do Panamá (1826): perspectivas políticas, teóricas e jurídicas nas relações internacionais, 20 PAPEL Político Bogotá 238 (2015).

${ }^{5}$ Bolívar, supra note 3, at 211: "[U]n escudo de nuestro nuevo destino."

${ }^{6}$ Alexandre Ganan de Brites Figueiredo, Simón Bolívar: uma persistência latino-americana 78 (2015) (doctoral thesis, University of São Paulo), https://www.teses.usp.br/teses/disponiveis/84/84131/tde-13092016-151214/publico/2015 AlexandreGananDeBbritesFigueiredo.pdf.

${ }^{7}$ Comisión Presidencial, supra note 2, at 28: "Ya que tiene un origen, una lengua, unas costumbrez y una Religion, deberia por consiguiente tener un solo Gobierno."

${ }^{8}$ Alexandre Ganan de Brites Figueiredo \& Márcio Bobik Braga, Simón Bolívar e o Congresso do Panamá: O primeiro inte-

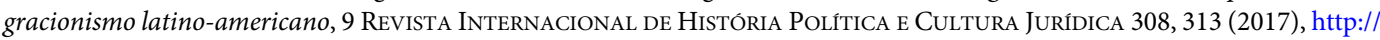
lorenzcolombiawww.redalyc.org/articulo.oa?id=337351121008.
} 
Professor José Carlos Brandi Aleixo devoted an entire paper into proving the close ties between Brazil and the ideals of the Congress of Panama, even though the country never attended the event. According to the author-even prior to the independence-several Brazilian authorities, such as Araújo Carneiro and Rodrigo Pinto Guedes, were fierce advocates of continental solidarity. In 1822, Don João VI himself, after fleeing from Napoleon to Brazil, proposed to its neighbors a Treaty of Confederation and Mutual Safeguard for the Independence. Also, José Bonifácio de Andrada e Silva - the "Patriarch" of the Brazilian independence-sought to create a league to defend the American countries against European imperialism. ${ }^{9}$

That is not the Brazilian history. One tends to forget that the four countries that attended the Congress of Panama were wary of the size of both Brazil and the United States, and that Brazil in particular was eyed with distrust, because its monarchic regime raised suspicions of the country's closeness to the Holy Alliance and its imperialistic policies. In 1825, the year before the Congress of Panama, the Chiquitos Incident provided a good reason for that distrust. Chiquitos was a Bolivian province that attempted to resist the revolutionary troops by pleading the protection of the Brazilian province of Mato Grosso. Mato Grosso initially agreed and answered the call by sending a small contingent. Pressure from the central government overturned the decision to aid the province, but the diplomatic incident was already established. ${ }^{10}$ In addition to that incident, there existed other important friction points. Brazil and Argentina quarreled over the status of Uruguay, and slavery constituted another issue that distanced Brazil from the Bolivarian ideals.

Moreover, the Bolivarian confederation was based on the common language and history of the Hispanic America, on the republican form of state, and on Catholicism. Brazil shares none of these grounds: The Portuguese-speaking country was a constitutional monarchy ruled by the house of Bragança-a European dynasty-whose Emperor was the heir to the throne of Portugal. The Brazilian Constitution subordinated the clergy and any Church rule to the Emperor's exequatur, a conception inherited from the Portuguese regalism. ${ }^{11}$ Brazilian authorities regarded religion with distrust and entrusted the Emperor with the power to restrain its "inappropriate" advances.

Indeed, few Brazilian leaders were in favor of some kind of continental solidarity against European intervention attempts. They were, however, much closer to the Monroe Doctrine than to Bolívar's beliefs of perpetual peace and supranational organization. In addition, according to Ganan de Brites Figueiredo, even this version of Americanism became well distanced from Brazilian politics after the demise of José Bonifácio de Andrada e Silva, only resurfacing in 1828 after the Congress of Panama. ${ }^{12}$

Furthermore, Bolívar himself clearly mistrusted Brazil's intentions towards the American continent. He regarded Brazil as an ally of the Holy Alliance. In a letter to General Francisco de Paula Santander, the Vice President of Grand Colombia, Bolívar pondered who was truly behind the military action in Chiquitos:

Thus, the Holy Alliance could not advise those hostile measures, because it would ruin his [the Brazilian Emperor] trade, his cause and would risk him being expelled from the throne.

\footnotetext{
${ }^{9}$ José Carlos Brandi Aleixo, O Brasil e o Congresso Anfictiônico do Panamá, 43 Revista Brasileira DE Política INTERNACIONAL 170 (2000), http://ref.scielo.org/72hcmw.

${ }^{10}$ Luis Cláudio Villafañe Gomes Santos, O império e as repúblicas do pacífico: as relaÇões do Brasil com o Chile, Bolívia, Peru, Equador e Colômbia (1822-1889) 23-26 (2002).

${ }^{11}$ It was a form of conceiving the relationship between the State and the Church prior to the modern lay state. In the Brazilian Constitution of 1824, Catholicism was the official religion, but that status did come with a price: The Emperor was the highest authority and should be consulted even in doctrinal issues. See Marco Aurélio Greca Casamasso, Estado, Igreja e Liberdade Religiosa na "Constituição Política do Império do Brazil," de 1824 [State, Church and Religious Freedom in the 1824 Political Constitution of the Empire of Brazil], in ANAIS DO XIX ENCONTRO NACIONAL DO CONPEDI 6167, 6169 (2010), https://s3.amazonaws.com/conpedi2/anteriores/XIX+Encontro+Nacional+-+UFC-Fortaleza $+(09 \% 2 \mathrm{C}+10 \% 2 \mathrm{C}+11+\mathrm{e}+12+$ de + junho+de+2010).pdf.

${ }^{12}$ Ganan de Brites Figueiredo, supra note 6, at 142.
} 
So, I imagine that the invasion of Chiquitos must be an absurd and hasty idea of Commander Araújo alone. If the Emperor is indeed behind this, without consulting the Holy Alliance, then it is an outburst of insanity without any consequence. But, if by chance this was advised by the Holy Alliance, then it is a matter of the utmost seriousness and dire transcendence. ${ }^{13}$

Even before the Chiquitos Incident, Bolívar believed that Brazil was cooperating with the Holy Alliance to disrupt the newly independent republics:

Moreover, I know that two thousand Germans and six thousand Russians have arrived in Brazil to support the Monarchist Party. It also seems certain that the King of Portugal has compromised his affairs with his son, the Prince of Brazil; all of this was done to reintroduce the principle of legitimacy in Southern America. Unfortunately, Brazil borders all our States; as a consequence, it is easy for it to successfully wage war against us, just like the Holy Alliance intended. In fact, I conceive that it would be very nice to the European aristocracy that the power of the Prince of Brazil should increase enough to destroy the seeds of our revolution. ${ }^{14}$

Therefore, the libertador was not in the least inclined to warrant, much less to expect and actively count on, a Brazilian presence in the Congress of Panama. German de la Reza affirms that the country was invited to the conference only to appease Great Britain. ${ }^{15}$ During the preparations for the conference, Briton George Canning constantly demanded from the Colombian representative assurances that the event would not become overtly anti-monarchic. Inviting Brazil was the appropriate response. ${ }^{16}$ In July 1825, the Grand Colombia plenipotentiary Manuel José Hurtado sent the invitation to Manoel Rodrigues Gameiro Pessoa, the Brazilian representative in London.

Still, Brazil could not care less. During the negotiations with Hurtado, Pessoa contended that the Brazilian city of Pará-now Belém, in the state of Pará-was a better location for the event because it was more central in America and closer to Europe. ${ }^{17}$ Unintentionally, or not, given the aspirations Bolívar nurtured with regards to Panama in the Charter of Jamaica, this request could

\footnotetext{
${ }^{13}$ Letter from Simón Bolívar to General Francisco De Paula Santander (May 30, 1825) http://www.archivodellibertador.gob. ve/escritos/buscador/spip.php?article11692.

La Santa Alianza, por lo tanto, no podía aconsejarle sus medidas hostiles, porque sería arruinarle su comercio, su causa y exponerlo a ser expulsado del trono. Así es que yo concibo que la invasión de Chiquitos debe ser una obra absurda y precipitada del comandante Araújo. Si es del emperador, sin consulta de la Santa Alianza, es un arrebato loco y sin consecuencia, y si es por consejo de la Santa Alianza, la cosa es de la mayor gravedad y su trascendencia inmensa.

${ }^{14}$ Letter from Simón Bolívar to General Francisco De Paula Santander (Jan. 23, 1825), http://www.archivodellibertador.gob. ve/escritos/buscador/spip.php?article8484.

Además, yo sé que al Brasil han llegado dos mil alemanes, y que vienen seis mil rusos a sostener el partido monárquico. También parece cierto que el rey de Portugal ha transigido sus negocios con su hijo, el príncipe de Brasil; todo con el fin de legitimar la América Meridional. Por desgracia el Brasil linda con todos nuestros estados; por consiguiente, tiene facilidades mucha para hacernos la guerra con suceso, como lo quiera la Santa Alianza. De hecho yo concibo que le será muy agradable a toda la aristocracia europea que el poder del príncipe del Brasil se extienda hasta destruir el germen de la revolución.

${ }^{15}$ Germán de la Reza, El Congreso Anfictiónico de Panamá. Una hipótesis complementaria sobre el fracaso del primer ensayo de integración latinoamericana, 8 ANUARIO DE HistORIA REGIONAL Y DE LAS FRONTERAS, July 2003, at 7, http://revistas.uis. edu.co/index.php/anuariohistoria/article/view/925.

${ }^{16}$ Dulce Portilho Maciel, Congresso do Panamá de 1826, união latino-americana sob tutela, in VIII SEMINÁRIO Internacional da Rede Ibero-Americana de Investigadores sobre GlobalizaÇão e Território. Grupo 3 Instituições, descentralização e participação na gestão regional e local, Ciudad de Mexico, UNAM, at 14, available at, https://slidex.tips/download/congresso-do-panama-de-1826-uniao-latino-americana-sob-tutela.

${ }^{17}$ In a letter to the Brazilian diplomat Luiz José de Carvalho e Mello, Manoel Rodrigues Gameiro Pessoa describes the conversation he had with Manuel José Hurtado in the following terms:
} 
only be perceived as a sign of disdain. At first, the Emperor accepted the invitation and sent the diplomat Teodoro José Biancardi. Before he could reach his destination, however, Biancardi received orders to return to Rio de Janeiro. ${ }^{18}$ Definitively, Brazil was not interested.

After the Congress of Panama, Mercosur's foundational myth becomes even more strained. It neglects over a century of Latin American history, because the Pan-American Conferences that were held under the auspices of the United States dominated the political agenda of this period. Those conferences were not "purely" Latin-American and drifted away from the purpose of creating a confederation formed by the former Spanish Empire. As Professor Celso D. de Albuquerque Mello asserts, Pan-Americanism is closer to Monroe than to Bolívar. ${ }^{19}$ The myth only resurfaced in 1960, with the creation of the Latin American Free Trade Association (LAFTA), and again in 1980 with the Latin American Integration Association (LAIA), but only insofar as Mercosur is its most successful offspring.

Then came 1985. Presidents José Sarney and Raul Alfonsín met in Foz de Iguazú and signed a Declaration recognizing the need to further bilateral trade. Brazil became Argentina's "preferential partner," and in July 1990, the Presidents Fernando Collor and Carlos Menem signed the Act of Buenos Aires, which aimed at creating a customs union as soon as 1994. In September of that same year, Paraguay and Uruguay manifested a strong desire to participate in that integration process, which led to the broadening of both scope and membership with the Asunción Treaty of March 1991, Mercosur's official birth.

\section{The Brazilian Perspective on Latin American Integration}

That story is a myth. As any good fable, it sits upon half-truths. Indeed, in Latin America, Simón Bolívar was the most important spokesman for integration. Yet, there are several different readings of that goal and not every path leads to Mercosur.

From the Brazilian perspective, integration dates back to the $1950 \mathrm{~s}$ with the Economic Commission for Latin America and the Caribbean (ECLAC)'s negative remarks on the classic theories of international trade. Raúl Prebisch, a former President of the Argentinian Central Bank, became ECLAC's Executive Secretary in 1950. In the course of that year and the year prior, he published three works that would deeply resonate with Latin American policy makers: El desarrollo económico de la América Latina y algunos de sus principales problemas, Estudio Económico de América Latina, 1949 and Problemas teóricos y prácticos del crecimiento económico. Prebisch engendered the thesis that underdevelopment consisted of a condition, rather than an economic stage, of which "underdeveloped" countries would never truly outgrow within a free trade global scenery. Less industrialized countries, such as those in Latin America, would gradually decrease

In a conversation with the Minister of Colombia, I proposed that, because the city of Pará is more central in the Americas and closer to Europe [than Panama], future American congresses should occur there; I believe this idea should be discussed in the Congress of Panama, and that, at the very least, said Congress should adopt the principle of shifting the location of the subsequent meetings.

(Em conversação que tive com o Ministro de Columbia avancei a proposição de que, estando a Cidade do Pará no ponto o mais central da America, e o mais proximo da Európa, éra ali que se deverião installar os futuros Congressos Americanos; e parece-me que esta idéa deve ser reproduzida no Congresso de Panamá, e que ao ménos se deve adoptar o princípio de alternar-se o lugar das subsequentes reunioens.)

Excerpt from the letter from Manoel Rodrigues Gameiro Pessoa, Minister Plenipotentiary of the Brazilian Empire in Great Britain, to Mr. Luiz José de Carvalho e Mello, Brazilian diplomat (Nov. 30, 1825), in 1 CADERNOS Do CHDD n.2 27 (2003), available at http://www.funag.gov.br/chdd/index.php/cadernos-do-chdd?id=82.

${ }^{18}$ Alvaro Teixeira Soares, Das origens do panamericanismo à União Panamericana 5 (Rio de Janeiro Imprensa Nacional 1940).

${ }^{19}$ Celso Renato Duvivier de Albuquerque Mello, Direito Internacional Americano, Editoria Central 53 (Universidade Gama Filho, Rio de Janeiro 1992). 
their role and significance in comparison to more industrialized nations. ${ }^{20}$ To overcome this, ECLAC recommended a more active role of governments in fueling the economy and, of course, Latin American integration.

At first, Brazilian authorities were reluctant to follow these instructions. In 1958, President Juscelino Kubitschek launched the OPA (Pan American Operation), a foreign policy based on the belief that the best medicine to contain the spread of communism was to eradicate poverty. Its core values were the protection of democracy in the American continent against communism, the preservation of private property, the enforcement of American solidarity, and the overcoming of underdevelopment as a common interest. According to Amado Cervo and Clodoaldo Bueno, however, that policy was rather vague and lacked concrete projects. The only accomplishment of a significant nature that it was able to achieve was the creation of the Inter-American Development Bank. ${ }^{21}$ Brazil called upon the United States to finance national development projects similar to the Marshall Plan. Surprisingly, the US did not deliver.

In that same year, the Brazilian perception took a considerable turn. Hélio Jaguaribe-a wellrenowned Brazilian historian-published the book O nacionalismo na atualidade brasileira, blaming the all-powerful and flawless Itamaraty - the Ministry of Foreign Affairs — of not being able to adjust to the new post-war scenery of international relations. He proposed that Brazil should pursue a foreign policy independent from the US, which would only be possible if the country were to strengthen its ties with Latin American policies, mainly those of Argentina. ${ }^{22}$ The underlying idea was quite simple: Brazil would have more leverage when negotiating with the US if it were not alone. In response, Itamaraty engendered the PEI—an acronym for "Independent External Policy" in Portuguese. In 1961, Presidents Jânio Quadros and Arturo Frondizi met in Uruguaiana and established a system of consultation and coordination of foreign policies. They spoke of a customs union that should gradually encompass other Southern American countries. This was a momentous event. The United States had always treated Latin America as a whole, but for the first time, issues of South American states alone were addressed. In history,

\footnotetext{
${ }^{20}$ Raúl Prebisch, El desarrollo económico de la América Latina y algunos de sus principales problemas, in 1 CINCUENTA AÑOS DE PENSAMIENTO EN LA CEPAL: TEXTOS SELECIONADOS 66 (1998) ("Countries that produce primary goods have their own share from the international trade. They ought never to industrialize. Instead, their less efficient economy will make them irrevocably loose the classic advantages of trade.") (“Mediante el intercambio internacional, los países de producción primaria obtienen su parte en aquel fruto. No necesitan, pues, industrializarse. Antes bien, su menor eficiencia les habría perder irremisiblemente las ventajas clássicas del intercambio.").

${ }^{21}$ Amado Luiz Cervo \& Clodoaldo Bueno, História da Política Exterior do Brasil 263 (1992).

${ }^{22}$ Hélio Jaguaribe states:

[I]t has become clear that the country does not display a true foreign policy, and that the Foreign Ministry, despite being composed by a body of highly qualified civil servants, a common trait especially among younger diplomats, was used to routinely apply old precedents, most of them dating back to the Rio Branco era, and, because of that, they stemmed from a totally different correlation of forces between Brazil and the other nations that exists today.

([T] ornou-se patente o fato de que o país não dispunha, realmente, de uma política externa e que o Ministério das Relações Exteriores, a despeito de contar com um corpo de funcionários de elevada média de qualificação, especialmente entre os diplomatas das gerações mais novas, se encontrava adstrito à rotineira aplicação dos precedentes, quase sempre remontando à época de Rio Branco e que, por isso, correspondiam a uma correlação entre o Brasil e as demais nações totalmente distinta da que hoje se verifica.)

And several pages later:

The first condition to neutralise the US' power of reprisal is to unite Latin America, and this process should be based on a close and functional connection between Brazil and Argentina. The rivalry between the two countries, although comprehensible in the colonial era, has become illogical for both ever since they began to develop. (A primeira condição para neutralizar o poder de represália dos Estados Unidos é a união da América Latina, baseada numa estreita e operante vinculação entre o Brasil e a Argentina. A rivalidade brasileiro-argentina, compreensível na fase colonial e semicolonial dos dois países, tornou-se, para ambos, a partir do momento em que enveredaram pelo caminho do desenvolvimento econômico-social, um contrassenso cada vez mais oneroso.)

Hélio Jaguaribe, O nacionalismo na atualidade brasileira, in Helio JAGUARIBE COLLECTION 284, 356 (2013), http://funag. gov.br/biblioteca/download/colecao-helio-jaguaribe.pdf.
} 
much separates an actual historical cause from an event that merely serves as inspiration. As Carlos Vidigal observes, the Uruguaiana Meeting "is the only consistent historical milestone for the beginning of South-American integration as we know it in the first decades of the XXI century." 23

The Uruguaiana Treaty was ratified only by the Frondizi administration and was subsequently discarded by the succeeding military presidents of both countries in favor of a policy more aligned with the United States. Brazilian presidents, however, still aspired to strengthen commercial ties with other South American countries - especially Argentina-and the Wheat Agreement of 1964 and the Iguazu Waterfalls Act of 1965 are both significant attempts at that. The most ambitiousyet unsuccessful-attempt of integration from this period was a customs union treaty with Argentina, conceived by Roberto Campos, who was a former alumnus of the University of Chicago and by then the Brazilian Ministry of Economy. In sum, Brazil persisted in the same policy of the $1960 \mathrm{~s}$ but without the ECLAC lens and with a more classical liberal approach. Nevertheless, our neighboring countries still perceived it as imperialism. During the negotiations, the Argentinian Chancellor Miguel Angel Zavala Ortiz stated very clearly that should Brazil desire to exercise leadership in Latin America, Argentina would become an obstacle rather than a partner. $^{24}$

Indeed, Brazil did relate poorly with its neighbors. The signs of mistrust were not entirely ill founded. In 1969, in a conference at the ESG (the Superior War School), ${ }^{25}$ the Brazilian Chancellor Alarico da Silveira Junior contended that Brazil should foster a true philosophy of economic cooperation in Latin America under the country's leadership and control. By insisting on Brazil's explicit leadership, he was in fact succeeding in antagonizing Argentina even more. Still, the Brazilian authorities had a fair idea of how integration should develop. Alarico da Silveira Junior resumed his speech by saying that international organizations should not exert a significant influence over said process. Despite their capacity for being more technical than any government, in international relations the best technical solution is not always the best political alternative. Those entities should not possess co-responsibility in formulating, coordinating, and much less conducting any multinational project of economic development. ${ }^{26}$ Hence, the Brazilian government did foresee the possibility of supranational organizations leading the process of Latin American integration. But unlike the Bolivarian project, that was not desired.

During the administrations of Ernesto Geisel and João Baptista Figueiredo, the correlation of forces between the two countries changed drastically in favor of Brazil. The country experienced a period of significant economic development known as the "milagre" — the miracle-between the years of 1969 and 1973, while Argentina went into a downward spiral. And yet, Brazil's diplomatic tone had eased somewhat, becoming more prudent when speaking of leadership in Latin America. ${ }^{27}$ In 1979, Argentina, Brazil and Paraguay signed the Tripartite Agreement that ended a bitter conflict between the first two over the Itaipu Hydroelectrical Plant and the use of the river Paraná. The agreement settled over ten years of dispute and represented a new landmark of cooperation. In 1982, Brazil's rather ambiguous neutrality in the Falkland's War greatly benefited Argentina: Brazil was against the war but supported the Argentinian claim over the island and provided discrete, albeit effective, military aid. ${ }^{28}$

\footnotetext{
23“[É] o único marco historicamente consistente para o início da integração sul-americana, tal qual a concebemos nas décadas iniciais do século XXI." Carlos Eduardo Vidigal, A Integração Sul-Americana como um Projeto Brasileiro: de Uruguaiana às Malvinas, in A AméRICA do Sul E A InTEgraÇão Regional 63, 65 (2012).

${ }^{24} I d$. at 71.

${ }^{25}$ During the Brazilian military regime, the ESG was the most important center for strategical thinking.

${ }^{26}$ Vidigal, supra note 23 , at 73 .

${ }^{27}$ Henrique Altemani de Oliveira, Política Externa Brasileira 148 (Saraiva ed., 2005).

${ }^{28}$ José Marcos Castellani Fajardo, Acordo Tripartite Itaipu-Corpus: Ponto de inflexão entre a disputa geopolítica e a política de cooperação 115 (2004) (unpublished master's thesis, Federal University of Rio Grande do Sul), https://lume.ufrgs.br/ bitstream/handle/10183/6148/000437450.pdf?sequence $=1$.
} 
The democratic governments of José Sarney and Raul Alfonsín carried on with the bilateral understandings. As Ambassador Marcos Azambuja contends, the history of LAFTA and later LAIA is one of many failures, and the two leaders successfully circumvented it. ${ }^{29}$ Although Mercosur was later registered in LAIA's Secretariat as one of its partial agreements, by then both countries did not want negotiations to occur within the framework of previous attempts at integration. The general idea was that they should endeavor something new.

\section{The Institutional Structure of Mercosur}

So, on March 26, 1991, Brazil, Argentina, Paraguay and Uruguay signed the Treaty of Asuncion, which was complemented by the Ouro Preto Protocol of December 17, 1994. Both treaties are credited for creating the international personality of the southern common market of Mercosur. Chile and Bolivia joined Mercosur as associate members on June 25, 1996 and on February 28, 1997, respectively. Venezuela became a member on July 13, 2012 but was suspended as of August 5, 2017. Mercosur's main purpose is to create a common market for the free movement of goods, services, and factors of production. With a view of ensuring better cooperation among member states, Mercosur also endeavors to set in place common foreign policies and common macroeconomic policies, as well as to harmonize national laws, as provided for in Article 1 of the Treaty of Asunción. Mercosur takes the form of an international intergovernmental organization devoid of supra-nationality in which decisions are taken by consensus, according to Article 16 of the Treaty of Asuncion and Article 37 of the Ouro Preto Protocol. All member states exert the Pro Tempore Presidency, alternating in alphabetical order every 6 months, as established in Article 12 of the Treaty of Asunción.

Article 1 of the Protocol of Ouro Preto divides Mercosur's organizational structure into the following bodies: The Common Market Council (CMC), the Common Market Group (GMC), the Mercosur Trade Commission (CCM), the Parlasul, the Economic and Social Advisory Forum (FCES), and the Mercosur Administrative Secretariat (SAM). ${ }^{30}$

The Common Market Council (CMC) is Mercosur's highest body, composed of the Ministers of Foreign Affairs and Economy of the member states. As an eminently political organism, it bears the ultimate responsibility for the achievement of regional integration. Its decisions are mandatory. ${ }^{31}$ As it is composed of high state officials, however, the CMC is often more concerned with governmental sensibilities than common goals.

The Common Market Group (GMC) is the executive arm of Mercosur and is comprised of the Ministers of Foreign Affairs and Economy, as well as the representatives of member states' central banks. ${ }^{32}$ It meets four times a year, and its resolutions are not binding.

The Mercosur Administrative Secretariat (SAM) — formerly the Secretary of the GMC - is the closest thing to a loose supranational institution within the structure of Mercosur and is comparable to the GATT Secretariat before the Uruguay Round. Yet, the SAM fulfills bureaucratic functions only, such as serving as depositary of documents, reporting the activities of the GMC, and providing general administrative support for the CMC, GMC, and CCM. It lacks the power to make recommendations of any kind and is subordinated to the GMC. ${ }^{33}$

\footnotetext{
${ }^{29}$ Marcos Castrioto de Azambuja, O reordenamento Sarney-Alfonsín, in A AMÉRICA DO SUl E A INTEGRAÇão REGIONAL 80 (2012), https://lume.ufrgs.br/bitstream/handle/10183/6148/000437450.pdf?sequence=1\&isAllowed=y.

${ }^{30}$ For a brief description of Mercosur's bodies, see the institution's official website, available at http://www.mercosur.int.

${ }^{31}$ Additional Protocol to the Treaty of Asunción on the Institutional Structure of MERCOSUR, art. 9, Dec. 17, 1994 [hereinafter Protocol of Ouro Preto].

${ }^{32}$ Treaty Establishing a Common Market between the Argentine Republic, the Federal Republic of Brazil, the Republic of Paraguay and the Eastern Republic of Uruguay, art. 13, Mar. 26, 1991 [hereinafter Treaty of Asunción]; Protocol of Ouro Preto, art. 10.

${ }^{33}$ Luiz Olavo Baptista, O Mercosul após o Protocolo de Ouro Preto, 10 Estudos AvanÇAdos 179, 184 (May/Aug. 1996), http://www.scielo.br/scielo.php?pid=S0103-40141996000200011\&script=sci_arttext\&tlng=es.
} 
The Mercosur Trade Commission (CCM) oversees the application of common trade policies established among the member states for the development of customs' union. It also keeps track of, and reviews, issues related to the countries' own common trade policies, as well as the intraMercosur and third-party states' trade-flow. Aiding the Commission, there exist several "Technical Committees" that function as auxiliary thematic dependent forums. The CCM is composed of eight members that are nominated by Mercosur's member states and is - collectivelymanaged by the member states' Ministries of Foreign Affairs. It convenes at least once a month, or whenever the Common Market Group (GMC) or any of the member states so requires. The Commission's decisions are called "directives" and serve as open guidelines mandatory to member states.

The Economic and Social Advisory Forum's (FCES) primary objective is to promote economic and social growth within Mercosur, as well as to strengthen its common market and its economic and social cohesion. The Forum also keeps track of and evaluates the economic and social impact of the integration policies that are adopted within Mercosur, be it on sectorial, national, regional, or international level. It also submits norms and economic and social draft policies and makes recommendations on other integration matters to the Common Market Group (GMC), or the other bodies, regarding Mercosur's internal affairs or relationships with non-member states, international organisms, and other integration initiatives.

Mercosur's Parliament (Parlasul) is a one-chamber, democratically-elected institution that was created in 2005 and took over the functions of the now extinct Joint Parliamentary Commission (CPC). This body was envisioned to become a real supranational authority within Mercosur, but it is not yet fully functional. Any, and all, formal acts are voted and decided in Parlasul's Plenary Sessions, held ten times per year in its headquarters in Montevideo-or in the territory of any member state should one require it. There are ten permanent commissions within Parlasul, each organized around specific subjects. Each commission is integrated by fourteen parliamentarians who study and analyze their respective legislative theme in order to assist Parlasul's Plenary Sessions.

Initially, the Parliament was made up of eighteen parliamentarians from each country, chosen out of each member state's national congress. In a Plenary Session in 2009, Parlasul approved a Political Agreement that set forth the direct election of its parliamentarians according to the following ratio, which was determined by demographic criteria: Argentina would elect 43 representatives; Brazil 75; Paraguay 18; Uruguay 18; and Venezuela 33, were it not suspended. It is expected that by 2020 all members of Parlasul will be directly elected; as of yet, however, Brazil, Uruguay, and Venezuela still appoint their representatives out of members of their respective congresses. Should Bolivia acquire full membership status within Mercosur, it will elect eighteen parliamentarians. ${ }^{34}$ Although envisioned to be a supranational body within an intergovernmental structure, when, and if, it becomes fully operational, Parlasul shall possess only advisory powers.

Finally, Mercosur has its own mechanism of dispute resolution. Signed on December 17, 1991, the Protocol of Brasilia created an intricate system of diplomatic negotiations and arbitration within Mercosur. On February 18, 2002, the Protocol of Olivos perfected this system by setting up a judicial appellate body, the Permanent Court of Revision. Luiz Olavo Baptista clarifies that Mercosur enjoys, in essence, a diplomatic cooperation mechanism complemented by a classical system of international arbitration that, in practice, can only solve conflicts between member states. ${ }^{35}$ At best, individuals and private companies may reach this system by provoking the acting of their own states. The implementation of the Permanent Court of Revision has done nothing to change this.

It seems quite clear that Mercosur did not result from the Bolivarian ideals and the Congress of Panama of 1826. It embodies different history, goals, and values. There exists no relation of cause and effect. The only similarity between the two events is that both constitute expressions of Latin American solidarity. To find further correlation between them is to broaden the law of causality

\footnotetext{
${ }^{34}$ Parlasur, Mercosur, at <https://www.mercosur.int/quienes-somos/parlasur/>, (last visited May 6, 2019).

${ }^{35}$ Baptista, supra note 33 , at 182 .
} 
beyond recognition, unless one employs an extremely vague notion of integration and adopts the misleading notion that Mercosur was simply destined to happen, as if every time someone spoke of Latin American integration, history moved closer and closer towards Mercosur.

Indeed, the foundational myth that Mercosur derived from Bolivarian ideals of integration can be used for legitimizing purposes. Policymakers and politicians in general may well invoke it in their speeches, but scholars should know better. But why is the myth so well spread? Granted, repetition and inertia amongst scholarly works are fair explanations. Yet, there appears to be another, more obscure reason.

\section{E. The EU Analogy}

The first years of Mercosur were marked by extreme enthusiasm. After a mere fifteen years in the making, however, successive delays of commercial goals put a heavy strain on the whole process of integration. Mercosur became paralyzed in the stage of an incomplete customs union. Brazilian experts on communitarian law looked upon the European Union for answers, and academic writings comparing the two regions became something of a trend. They responded almost unanimously with what can only be termed as an "EU analogy": The spill-over method was not fully observed and Mercosur should possess supranational institutions. Mercosur was failing because it did not follow in the EU's footsteps.

Whether Mercosur should indeed follow in the EU's footsteps is beyond the purpose of this Article. The point is that this solution purported to resume Mercosur's original goals. Not the goals of 1991 with the Asunción Treaty and the common market, but those of 1826 with Bolívar and a Latin-American Confederation of states.

Comparisons between the two processes were bound to occur. ${ }^{36}$ The European Union is older, larger, and more successful than Mercosur. Therefore, the European experience has much to offer and teach. As Giovanni Sartori contends, however, there are good and bad comparisons, and one cannot draw a comparison between cats and dogs. ${ }^{37}$ To examine one experience in contrast with another, and to extract useful results therefrom, represents no minor endeavor; it entails choosing a proper method and carefully selecting the rules or legal institutes of each compared system that will serve as basis for such comparison. Unfortunately, scholars that resort to the EU analogy tend to offer nothing but vague explanations and obvious generic analysis: They compare both systems as a whole as they confront all communitarian institutions and discard their differences, leaving no room for subtleties.

Again, the examples abound. For instance, in his Master thesis, R. F. F. assumes from the very start that the European Union was Mercosur's paradigm, and this is never explained. He begins his 143-page work by giving an account of the first pre-historical people who lived in the Iberian Peninsula, then the pre-Roman civilizations, the Romans, the Visigoths, the Muslims, and, finally, the Spaniards and the Portuguese as well as the law they developed. He then describes the Latin American colonization and, of course, Simón Bolívar's ideals of integration. After that, he touches on the creation of certain international economic organizations - such as the WTO, LAIA, the Andean Community of Nations, Mercosur, the EU, and the FTAA proposal. With that background in mind, R. F. F. attempts to compare the sources of EU and Mercosur law, and to analyze the tax law harmonization processes of Mercosur. Lastly, the author describes the institutions of

\footnotetext{
${ }^{36}$ Comparisons between Mercosur and the EU are quite common in the Brazilian literature, more common than in any other country from Mercosur. For "good" comparisons, see generally EliZABETH ACCIOLY, Mercosul E UNIÃO EUROPEIA, Estrutura Jurídico-Institucional (Juruá Editora 2d ed., 1999); Deisy Ventura, As assimetrias entre o Mercosul e a UNIÃo EUROPÉIA (Manole ed., 2003).

${ }^{37}$ See generally Giovanni Sartori, BIEN COMPARER, MAL COMPARER, 1 REVUE INTERNATIONALE DE POLITIQUE COMPARÉE 19-36 (1994).
} 
the Andean Community of Nations. From those axioms, he arrives at the fair and logical conclusion that "any attempt to overcome the obstacles within the various steps of integration will remain insurmountable, unless we adapt the constitutions of the member-states to accept the supra-nationality character of Mercosur's law." 38

Why is the European Union integration so enticing for Latin American students of Mercosur? Because-albeit the clear differences in structure and history - it has acquired a status of nothing short of a paradigm. R. F. F. himself contends that. He explains that his purpose was to address Mercosur law from the perspective of Community Law, and then argues that, therefore, one must first describe "the European Union steps of integration, as a qualified paradigm for Mercosur that lies obviously in a more advanced stage of integration, since it is 40 years ahead of the Mercosurean project and, by doing so, one may sketch a valuable comparison." 39 R. F. F. then briefly depicts the well-known stages of the European integration as if they were mandatory or the only possible stages for any attempt of integration.

That kind of reasoning holds an implicit conclusion: Compared to the EU, Mercosur is on its infancy because it has not taken all the necessary steps the former had; the keywords here being "infancy" and "necessary." Not surprisingly, Hedley Bull argues that students of the international society should never rely on the so-called "domestic analogy," not only because attempting to understand something by means of something else is a sign of infancy in a subject, but also because the international society is unique and will not develop such as the national society did. ${ }^{40}$ By the same token, this kind of Brazilian literature believes that the EU is forty years ahead of Mercosur and experienced the only possible stages of integration. In other terms, the EU is the "grownup" counterpart of Mercosur. This image is the precise essence of the EU analogy.

As M. M. M. and L. E. B. A. eloquently put it: "The tortuous path taken by Mercosur is not unique. It is the repetition in different dates of other attempts of regional integration." ${ }^{21}$ Here again, the authors display the idea of a single possible path to regional integration. "However, during these fifteen years, the integrational trend of Mercosur has been weakened by several maladjustments and conflicts that reveal individualistic behaviors [from the member states] that are not favorable for advancing and consolidating the bloc." And later on: "Today, integrational decisions remain bound to state will and are bereft of communitarian interests and so the progress of the integrational process in Mercosur becomes stagnant." 42 Hence, supranational institutions are the solution for this crisis.

\footnotetext{
38“Qualquer avanço no sentido de superar as dificuldades nas diversas fases da integração continuará intransponível sem a adequação das constituições dos Estados-partes no reconhecimento da supranacionalidade da norma Mercosulina.” René Alejandro Enrique Farias Franco, Direito Comunitário, o Processo de Integração Latino-Americano e o seu Paradigma Europeu 135 (Sep. 14, 2007) (unpublished master's thesis, Pontifical Catholic University of São Paulo).

${ }^{39} I d$. at 55.

Inicialmente, cumpre ressaltar que, no presente trabalho, optou-se por abordar o Direito do Mercosul sob o prisma do Direito Comunitário, ou no que lhe couber, trazendo inicialmente a colação, as fases de integração da União Europeia, na qualidade de paradigma do Mercosul, que obviamente encontra-se num estágio de integração mais avançado, produto de 40 anos a frente do projeto Mercosulino, para assim, poder traçar um comparativo ilustrativo das fases do processo de integração e o atual estágio do Mercosul.

${ }^{40}$ Hedley Bull, Society and Anarchy in International Relations, in Diplomatic InVESTIGATIONS: Essays IN THE THEORY OF InTERnational Politics 45 (Herbert Butterfield \& Martin Wight eds., 1966).

41 “O processo tortuoso percorrido pelo Mercosul não é inerente a ele unicamente. É a repetição da história, em datas diferentes, de outras tentativas de integração regional.” Mónica Montaña Martínez \& Luis Ernani Bonesso de Araújo, Análise Comparada da Integração no Mercosul e na União Europeia, 2 Revista dos Alunos do Programa DE PósGraduAÇão EM INTEGRAÇÃo LATINO-AMERICANA, 2005, at 7.

${ }^{42} I d$. at 6, 13. "Entretanto, a visão unificadora e expansionista do Mercosul tem sido debilitada durante estes quinze anos por múltiplos desajustes e conflitos, que revelam atitudes individualistas e desfavoráveis para o avanço e consolidação do bloco." And "Atualmente, as decisões integrativas permanecem vinculadas às vontades estatais, desprovidas dos interesses comunitários, ficando pendente a permanência e evolução do processo de integração no Mercosul.”
} 
The notions that the EU constitutes a paradigm for Mercosur and that supranational institutions represent the solutions for Mercosur's mishaps appear in all the EU analogy literature. When analyzing a perceived deficiency in Mercosur-and sometimes a certain characteristic can only be considered a "deficiency" in comparison to the EU-the author always propounds a supranational institution to overcome this. For instance, J. F. G. analyzes the instruments for harmonization of law in both Mercosur and the EU_"'the most developed integrational process." In Mercosur, harmonization mainly stems from the decisions, resolutions, and directives of the CMC, GMC, and CCM, respectively; because these are not supranational bodies, the whole operation is more "imprecise" and "less effective" than in the EU. Yet, the only evidence presented in the paper to support this is the case study of Consumer Law, which-as J. F. G. contends - failed in both regions because of the same reason. ${ }^{43}$ Clearly, that conclusion does not follow from this one premise.

Even governmental officials resent the absence of supranational institutions in Mercosur. In the Fifth Meeting of the Supreme Courts from the member states of Mercosur, Ellen Gracie, former president of the Supremo Tribunal Federal (the Brazilian Supreme Court), delivered a speech to evidence that a system of consultation to national courts would be desirable. She abruptly remarked that the absence of this system and that of "a supranational panel that should uniform the interpretation of law caused, in large measure, the modest integration we have reached, even after all these years." 44 Once again, the notion that a supranational organization should solve any country's problems seems, oddly, universal. Although she did not mention explicitly the European Union, the EU analogy was certainly not far from her mind, because the CJEU can uniformize the interpretation of communitarian law. Moreover, Mercosur can only be deemed a "modest" system of integration in contrast with the EU.

Often, the literature of the EU analogy displays the foundational myth as well. L.A.C., in comparing both systems as a whole, considers the Congress of Panama of 1862 and Bolivarianism as the origins of Mercosur. More accurately, the author says that there can be two different explanatory approaches regarding the beginning of Mercosur: One focused on the relations between Brazil and Argentina and another centered on Simón Bolívar. He rapidly dismisses the first on behalf of a "broader and more comprehensive approach." In the end, L. A. C. does realize that he cannot reach any conclusion for his endeavor, but he still risks drawing a "partial and inconclusive" judgment: The feeble political will and-of course - the absence of supranational institutions are the main reasons why Mercosur is less "evolved" than the EU. ${ }^{45}$

As seen in the above quotations, the EU analogy is but a mere reference; it does not amount to a true comparison between both systems. As perceived by each author, the European integration represents a successful model due mainly to its supranational character. And these authors believe that needs no further explaining because the lesson is such a commonplace in the Brazilian literature. Mercosur is thus in crisis precisely because of its intergovernmental feature: Overzealous of their sovereignty, the member states will not let Mercosur achieve its full potential. The underlining idea here is that the governments are holding back the "true forces" of Latin American integration.

And how can one know what those true forces are, if they indeed exist? The foundational myth conveniently rises to the occasion at this very point by purporting that the idea of creating

\footnotetext{
${ }^{43}$ Joséli Fiorin Gomes, Harmonização Jurídica na União Europeia e no Mercosul: a dialética construção da integração regional [Legal Harmonization in the European Union and Mercosur: The Dialetic Construction of Regional Integration], in ANAIS Do XXI EnCONTRo Nacional DO CONPEDI-UberlÂNDIA 6238, 6262 (2012), http://www.publicadireito.com. br/artigos/?cod=06138bc5af602364.

${ }^{44}$ Ellen Gracie, President of the Brazilian Federal Supreme Court, Opening Speech at the 5th Meeting of the Supreme Courts of MERCOSUR (Nov. 8, 2007), at http://www.stf.jus.br/bicentenario/publicacao/verPublicacao.asp?numero=245000. ("Tal fato, somado à ausência de uma instância supranacional uniformizadora da interpretação desses textos legais, leva em boa parte ao resultado de modesta integração que temos logrado, passados todos esses anos."). In fact, Ellen Gracie was wrong: Since 2002, there is a form of uniformizing the interpretation of the communitarian law in Mercosur.

${ }^{45}$ Carvalho, supra note 1 , at 72,90 .
} 
supranational institutions subsisted in the very first proposal of Latin American integration. A great man such as Simón Bolívar understood the longings of the peoples far better than any government. If petty governmental interests were to be removed from the process, Latin American integration would resume its early and true history. As curious as it may seem, the EU analogy relies heavily on the foundational myth.

S. G.'s work depicts this reasoning to perfection. His paper seeks to find a solution for the current dilemma that Mercosur faces by resorting to its own history. Indubitably, the first part of the work displays the foundational myth. After that, the author depicts Mercosur's institutions and perceives a problem with the settlement of disputes between member states. Evoking the Court of Justice of the European Union and the primacy therein attributed to Communitarian Law, S. G. firmly believes that "a better functioning of Mercosur's 'communitarian justice' lies on the creation of a supranational court." His last sentences are quite revealing: "Only by doing so we may fulfil the Bolivarian ideal of forging ties of solidarity between the countries and freedom and unity are its driving force. That is the path. After all, who knows what the future reserves?"46

\section{F. Conclusion}

Although surprisingly common, the (in)famous "domestic analogy" - the mechanical extrapolation of domestic rules or legal concepts to International Law-leads to grave methodological errors. As Michel Virally contends, the use of the domestic analogy lies on a very disputed assumption: That there exists only one kind of law, which is national law, and that international law should not develop but in accordance thereto. ${ }^{47}$ In effect, that reveals a lack of imagination.

By the same token, the "EU analogy" establishes that the only possible form of integration is that of the European Union, and as such, Mercosur should follow its lead. It assumes that supranational institutions are desirable, regardless of any financial strain on the budget of the member states. Stripped down to its bones, the EU analogy is not a real comparison, but a vague reference to the European experience made without any rigor and employed simply for legitimizing purposes.

This mental exercise becomes even more convincing when relying on a fabricated origin. If the idea of instituting a supranational organization were to be familiar to Mercosur's history, then shaping it to resemble the EU as if that would ensure its success would become more compelling. This is the reason why some Brazilian communitarian experts portray the origins of Mercosur as dating back to the Congress of Panama of 1826: As their arguments appear more attractive, this enables them to sell whatever solution they have concocted. And the most important prize is to be right about Mercosur's fate-especially at the expense of governmental policies-because said destiny appears to be the will of the founding father.

\footnotetext{
${ }^{46}$ Guerra, supra note 1, at 292-93. "Entende-se que para melhor funcionamento de uma futura 'justiça comunitária' no Mercosul, esta deverá ser viabilizada mediante a criação de um Tribunal Supranacional.” And: “Só assim se poderá concretizar o ideal bolivariano de formar vínculos de solidariedade entre os países, sendo a liberdade e a união a força motriz destes. Esse é o caminho. De toda sorte, quem sabe o que o futuro reservará?"

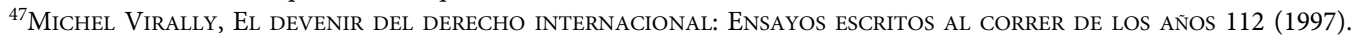

